\title{
The Impact Of Organizational Factors On Implementation Outcomes Of Lean Manufacturing
}

\author{
Homayoun Bayat, Oakland University, USA
}

Mohammad Dadashzadeh, Oakland University, USA

\begin{abstract}
Critical success factors for successful implementation outcomes of lean manufacturing remain an important area of research. This paper examines the correlation between organizational factors, organizational structure, and job design with implementation outcomes of lean manufacturing that impact quality, waste, and delivery. The effect of three moderating factors, the length of time that lean manufacturing has been implemented, the company's size, and the type of manufacturing, on the relationship between organizational factors and implementation outcomes of lean manufacturing is also studied. The results of this research study indicate that except for the lack of a relationship between level of formalization with waste and delivery outcomes, there are significant positive correlations between organizational factors and implementation outcomes of lean manufacturing. The results also indicate that the moderating factors do affect the relationship between independent and dependent variables.
\end{abstract}

Keywords: Lean Manufacturing; Organizational Success Factors

\section{INTRODUCTION}

Qf ean is a combination of a set of principles, practices, tools, and techniques with an aim to improve quality, delivery, cost, and customer satisfaction by eliminating three main sources of loss: variability, waste, and inflexibility (Drew, McCallum, \& Roggenhofer, 2004). Hoyte and Greenwood (2007) stated that there is continuing increase in demand for adopting lean strategies, acknowledging the fact that lean implementation is difficult and may fail. Manufacturing organizations need to consider, evaluate, and analyze the role of organizational factors as a major task in any process or program implementation. Although many researchers have pointed out the important role that organizational factors play in the implementation of lean manufacturing, most studies are based on lean tools implementation and the results of its performance on lean implementation. Worley and Doolen (2014) reported the impact of organizational structure on lean implementation and how it can lead to increased development of employee problem-solving skills. Wickramasinghe and Wickramasinghe (2011) found out that participative decisionmaking and propensity for participative decision-making significantly differ by the duration of lean production in operation. Laureani and Antony (2012) contrasted the critical success factors for the effective implementation of Lean Six Sigma in manufacturing and service organizations. Alony and Jones (2008) extensively reviewed studies of humanrelated and organizational factors in the context of lean manufacturing. They identified gaps in the research in this area and emphasized the necessity for research on organizational factors that support the adoption of lean manufacturing. A more recent research review (Bayat \& Dadashzadeh, 2016) shows that although empirical research on the relationship between an organizational factor such as job design and an outcome dimension such as quality have started to emerge, a multidimensional study of organizational factors and outcomes remains a needed contribution to the understanding of critical success factors for successful implementation outcomes of lean manufacturing.

The empirical study reported in this paper addresses the multidimensional examination of the relationship between organizational factors and implementation outcomes of lean manufacturing per participating managers' perception of organizational factors and three implementation outcomes of lean manufacturing. Specifically, this study focuses on the following three organizational factors: organizational climate (with specific dimensions of open-mindedness, creativity and continuous improvement), organizational structure (with specific dimensions of centralization, integration, and 
formalization), and job design (with specific dimensions of skill variety, task identity, task significance, autonomy, and feedback). Since the objective of lean is to optimize quality, waste, and delivery (Drew et al., 2004), this study gathers data on the implementation outcomes of lean manufacturing by measuring quality, waste, and delivery. The research model is represented in Figure 1.

Figure 1. Research Model on Impact of Organizational Factors on Lean Manufacturing

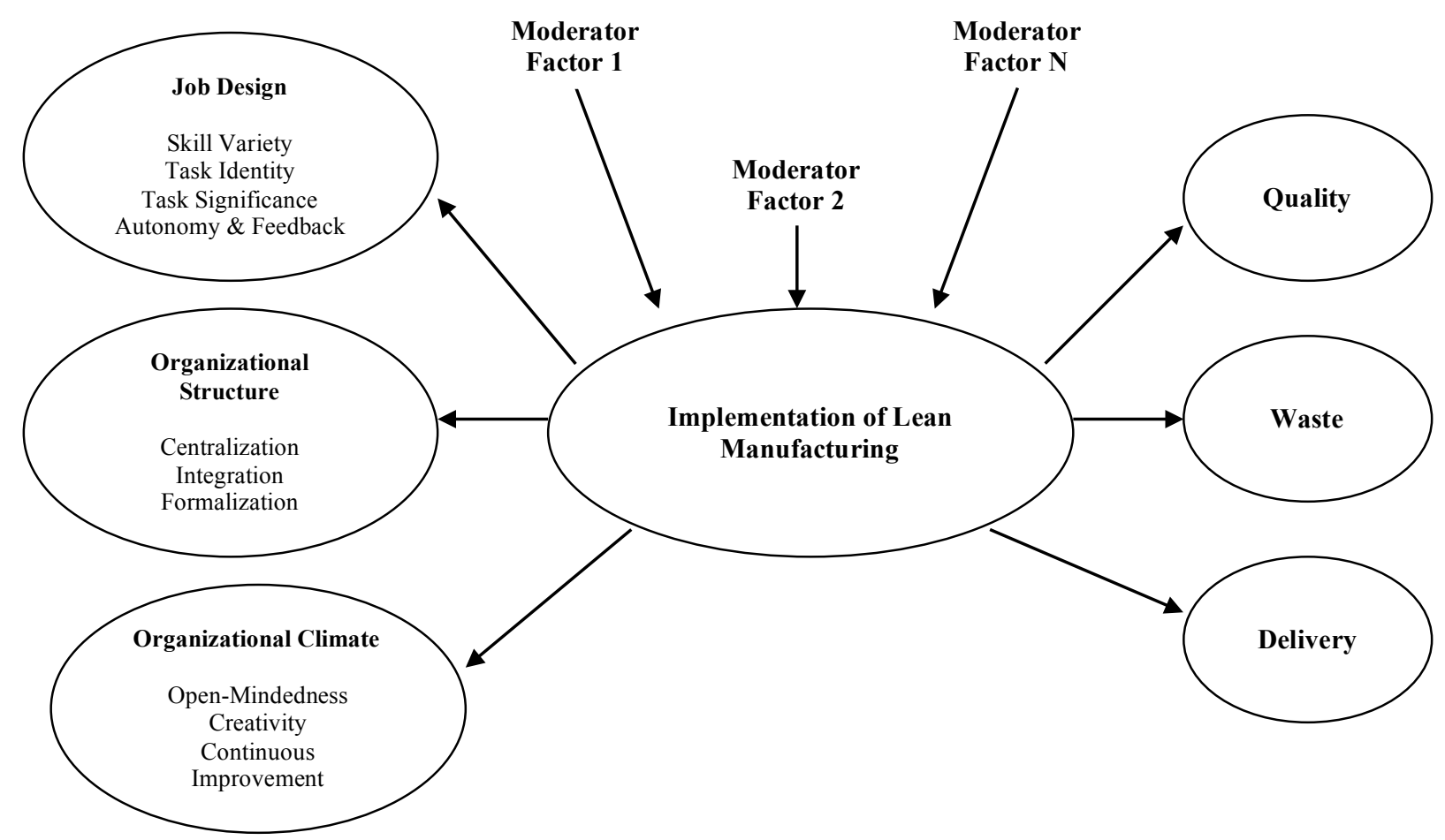

The remainder of this paper is organized as follows. In the next section, we detail the research methodology used and review the dimensions of organizational factors and dimensions of implementation outcomes of lean manufacturing that were selected in our research model per other researchers' studies reported in the literature. Section 3 discusses the results of the survey study and correlation analysis of the following research questions per participating managers' perception of organizational factors and the three implementation outcomes of lean manufacturing:

1. What is the relationship between organizational climate and the three implementation outcomes of lean manufacturing in manufacturing organizations?

2. What is the relationship between organizational structure and the three implementation outcomes of lean manufacturing in manufacturing organizations?

3. What is the relationship between job design and the three implementation outcomes of lean manufacturing in manufacturing organizations?

We conclude with summary and directions for future research.

\section{RESEARCH METHODOLOGY}

Leedy and Ormrod (2005) stated that often when researchers want to study correlation and understand how particular characteristics change as other characteristics change, they use one of two development designs. One is longitudinal study, which involves variation in response and participants due to data collection over a lengthy period of time, and the other is cross-sectional design in which all data can be collected at a single time (Leedy \& Ormrod, 2005). 
For this study, a cross-sectional research design was used, because there is an attempt to determine whether there is a relationship between organizational factors with the implementation outcomes of lean manufacturing in organizations that have implemented lean manufacturing.

\subsection{Measurement}

The information about dependent (implementation outcomes of lean manufacturing) and independent (organizational factors) variables was obtained from organizations' managers and engineers at a particular point in time when they responded to the questionnaire. The questionnaire asks participants questions regarding demographic information. An example of these eight demographic questions would be time with their company and knowledge of lean manufacturing. The questionnaire also asked participants to rank objectively each question as it describes the situations in their organization according to their knowledge and experience.

\subsubsection{Face Validity}

For two of the organizational climate dimensions in this study, open-mindedness and creativity (Payne \& Mansfield, 1978) and job designs (Hackman \& Oldham, 1976), the existing scales were used. Other scales were developed per review of related studies and literature, where face validity of the scales was examined. Scales were reviewed for relevancy of materials and content, format, and clarity and understandability by knowledgeable individuals on the subjects, to ensure that the scales measure what they are supposed to measure (Leedy \& Ormrod, 2005). The suggestions were all taken into consideration. Therefore, some items were removed from the scales and corrections were made to the other items. As a result of face validating the scales, the initial instrument containing 65 items was reduced to 50 items.

Also, in the reliability study, two more items, one from centralization and the other from formalization scales, were removed. The strong Cronbach's Alpha for internal consistency reliability also indicated the validity of this instrument.

\subsubsection{Reliability}

Leedy and Ormrod (2005) noted that reliability is the consistency of measuring instrument, and as validity it reflects the measurements' degree of error. For this study, the instrument showed very good consistency reliability. Scales for organizational climate and its three dimensions, scales for organizational structure and its three dimensions, scale for job design, and scales for implementation outcomes of lean manufacturing and its three dimensions demonstrated internal consistency reliability above .70 as suggested by Morgan, Leech, Gloeckner, and Barrett (2007). All scales for organizational climate dimensions (open-mindedness, creativity, and continuous improvement), organizational structure dimensions (centralization, integration, and formalization), job design (overall job design considered as one scale due to Motivating Potential Score (MPS) relationship), and implementation outcomes of lean manufacturing's dimensions (quality, waste, and delivery) demonstrated good internal consistency reliability (Table 1 and 2) above 0.70 (Morgan et al., 2007). Also, the internal consistency reliability for overall organizational climate instrument that consisted of thirteen items was $\alpha=.909$, for overall organizational structure instrument that consisted of ten items was $\alpha=.837$, and for overall implementation outcomes of lean manufacturing instrument that consisted of seventeen items was $\alpha=.933$.

Table 1. Independent Variables Reliability

\begin{tabular}{|c|c|c|}
\hline Scales & Number of Items & Cronbach's Alpha \\
\hline Open-mindedness & 4 & 0.893 \\
\hline Creativity & 4 & 0.813 \\
\hline Continuous Improvement & 5 & 0.831 \\
\hline Centralization & 3 & 0.708 \\
\hline Integration & 4 & 0.885 \\
\hline Formalization & 3 & 0.784 \\
\hline Job Design & 10 & 0.801 \\
\hline
\end{tabular}


Table 2. Dependent Variables Reliability

\begin{tabular}{|c|c|c|}
\hline Scales & Number of Items & Cronbach's Alpha \\
\hline Quality & 5 & 0.832 \\
\hline Waste & 8 & 0.899 \\
\hline Delivery & 4 & 0.884 \\
\hline
\end{tabular}

\subsubsection{Independent variables}

Organizational factors that consist of organizational climate, organizational structure, and job design were considered independent variables for this study.

Organizational climate. For this study, the following three dimensions of organizational climate were studied: Openmindedness, creativity, and continuous improvement. The open-mindedness and creativity scales each include four items that are based on Business Organization Climate Index (Payne \& Mansfield, 1978). The continuous improvement scale includes five items that are based on studies from Drew et al. (2004), Naveh and Erez (2004), Roffe (1999), Stern, Song, \& O'Brien (2004), ASQ - Index (2000), and the authors' personal work experience. The measurement scale for organizational climate was on a 5 -point Likert scale ranging from 1 (disagree) to 5 (agree).

Organizational structure. Centralization, integration, and formalization were studied as three dimensions of organizational structure. The measures for centralization that were developed by Hage and Aiken (1967) and the studies from Caruana et al. (1998), Cummings (1995), DeGroote and Brownlee (2006), Drew et al. (2004), and Jones (2010) were the basis for the development of a three-item scale for the centralization section.

To determine cooperation and collaboration, interaction and synchronization, differentiation or segregation between departments or groups, and utilization of the cross-functional team, a four-item scale was developed for integration based on studies from Doolen and Hacker (2005), Jackson and Martin (1996), Jones (2010), Lawrence and Lorsch (1967), and O’Leary-Kelly and Flores (2002).

The formalization scale consists of four items based on studies from de Treville and Antonakis (2006), Drew et al. (2004), Hage and Aiken (1967), Jones (2010), Liker (1998), Mehta and Shah (2005), and Womack et al. (2007).

Centralization, integration, and formalization are integrated and require organizations to have a right balance, for example between employee freedom in terms of flexibility, rules, authority, and standards (Jones, 2010). Therefore, for correlation study, organizational structure was studied as one scale (consisting of ten items) as well. The measurement scale for organizational structure is based on a 5-point Likert scale ranging from 1 (disagree) to 5 (agree).

A factor analysis was conducted on the combined organizational scale. The results indicate that three factors exist per the three delineated sub dimensions of the scale: centralization, integration, and formalization. One of the centralization items ("In our organization, there will be encouragement for individuals who want to make their own decision") loaded on the integration factor.

Job design. Hackman and Oldham's (1976) model consisting of five core job dimensions of skill variety, task identity, task significance, autonomy, and feedback, was used to develop a scale that consists of ten items (two items for each five core job dimensions). Hackman and Oldham's (1976) formula that measures the overall "motivating potential" of a job in terms of the five core job dimensions was used: Motivating Potential Score (MPS) of a job = autonomy * job feedback * [(task significance + task identity + skill variety $) / 3]$

Hackman and Oldham's (1976) formula for MPS is considered as one scale. The measurement scale for job design would be a 7-point Likert scale ranging from 1 (strongly disagree) to 7 (strongly agree).

\subsubsection{Dependent variables}

The implementation outcomes of lean manufacturing were considered as dependent variables for this study and measured along three dimensions. Three of the objectives of lean are to optimize cost, quality, and delivery (Drew et al., 
2004), and cost optimization requires elimination of all types of waste (Drew et al., 2004, Liker, 2004; Womack \& Jones, 2003). Therefore, quality, waste, and delivery were selected as dimensions for implementation outcomes of lean manufacturing.

The quality scale consists of five items based on the literature of Besterfield (1986), Broh (1982), de Treville and Antonakis (2006), Drew et al. (2004), Crosby (1979), Liker (2004), and Womack et al. (2007) and the authors' personal work experience. The eight-item scale for waste was developed based on studies and literature from Drew et al. (2004), Hicks (2007), Huge and Anderson (1988), Liker (1998), Ohno (1988), Shah and Ward (2003), Womack and Jones (2003), Womack et al. (2007), and the authors' personal work experience. The delivery scale also contains four items based on studies and literature from Drew et al. (2004), Huge and Anderson (1988), Womack and Jones (2003), Womack et al. (2007), and the authors' personal work experience. The measurement scale for all dimensions of the implementation outcomes of lean manufacturing utilized a 5-point Likert scale ranging from 1 (disagree) to 5 (agree).

\subsection{Population and Sample}

The population of this study was all North American organizations that implemented lean manufacturing. For this study, purposive sampling was used. For sampling, managers, supervisors, and engineers of North American manufacturing organizations that implemented lean manufacturing were targeted (Table 3). The responses from participants were anonymous. There were no company and participant name requirements for participating in this study; therefore, all information was confidential as it was explained in a letter of consent.

Table 3. Participants' Titles and Job Functions

\begin{tabular}{l|c}
\hline \multicolumn{1}{c}{ Participants' Titles and Functions } & Number of Individuals \\
\hline Vice President of Quality and Continuous Improvement & 1 \\
\hline Vice President for Production & 1 \\
\hline Company Executive for Lean Manufacturing & 1 \\
\hline Company Executive for Quality & 3 \\
\hline Company Executive for Production & 1 \\
\hline Company Executive for Marketing and Sale & 1 \\
\hline Company Executive & 2 \\
\hline Senior Quality Manager & 3 \\
\hline Senior Production Manager & 1 \\
\hline Senior Program Manager & 16 \\
\hline Quality Manager & 8 \\
\hline Production Manager & 2 \\
\hline Manufacturing Manager & 2 \\
\hline Engineering Manager & 1 \\
\hline Program Manager & 1 \\
\hline Sales Manager & 1 \\
\hline Human Recourses Manager & 19 \\
\hline Quality Supervisor & 7 \\
\hline Production Supervisor & 4 \\
\hline Engineering Supervisor & 1 \\
\hline Manufacturing Supervisor & \\
\hline Engineer & \\
\hline Note: $10.7 \%$ of Participants were VP and company executives, $44 \%$ were senior managers and managers, $36.9 \%$ were supervisors, and $8 \%$ were \\
engineers. & \\
\hline
\end{tabular}

\subsection{Data Collection}

A Survey Monkey link was created. Companies that implemented lean manufacturing, and individuals and experts who were working in companies that implemented lean manufacturing, were contacted by phone. After phone contacts, the survey was sent to those individuals by e-mail. All contacts were followed up with. After two months of data collection from 98 responses, 84 were complete responses. 
As indicated in Table 3, participants' positions varied. Questionnaires were filled out by vice presidents, executives, senior managers, supervisors, and engineers of different companies. A link was created and distributed throughout North American industries and data collected online. The participants were given three weeks from the date of receiving the questionnaire to take the survey. From the responses, the participating individuals from each organization were among vice presidents, company executives, senior managers, managers, supervisors, and engineers who participated in implementation of lean manufacturing in their organizations.

\subsection{Data Analysis}

Pearson correlation was used to analyze the relationship between organizational climate, organizational structure, job design, and implementation outcomes of lean manufacturing. SPSS was used to compute the Chronbach's alpha reliability and correlations of the variables. Multiple regression analysis of the combined independent factors on the implementation outcomes and factor analysis for organizational structure were studied.

\section{RESULTS AND ANLAYSIS}

In this section, we present the results of the study and discuss the three research questions addressed. The demographic section of the survey questionnaire requested information about participants' years of experience with their current companies and their years of experience with lean manufacturing. This information was used to understand the level of comprehension that participants have about their companies and lean manufacturing, and therefore to validate responses (Tables 4 and 5).

Table 4. Years of Participants' Experience with Lean Manufacturing

\begin{tabular}{l|c}
\hline \multicolumn{1}{|c}{ Participants' Experience with Lean } & Number of Participants \\
\hline 1 to 4 years & 15 \\
\hline 5 to 9 years & 40 \\
\hline 10 years and more & 29 \\
\hline
\end{tabular}

Table 5. Years of Participants' Experience with their Current Companies

\begin{tabular}{l|c}
\hline \multicolumn{1}{c}{ Participants' Experience with their Current Companies } & Number of Participants \\
\hline 1 to 4 years & 9 \\
\hline 5 to 9 years & 35 \\
\hline 10 and over & 40 \\
\hline
\end{tabular}

The participants were also asked about their companies' years of experience with lean manufacturing, number of employees in their companies, and their type of organization. The following data were used as moderator variables for this study (Tables 6, 7, and 8).

Table 6. Years of Companies' Experience with Lean Manufacturing

\begin{tabular}{l|c}
\hline \multicolumn{1}{|c|}{ Companies' Experience with Lean } & Number of Participants \\
\hline 1 to 4 years & 33 \\
\hline 5 to 9 years & 36 \\
\hline 10 years and over & 15 \\
\hline
\end{tabular}

Table 7. Size of Companies

\begin{tabular}{l|c}
\hline \multicolumn{1}{|c|}{ Company Size } & Number of Participants \\
\hline Up to 300 employees & 22 \\
\hline Between 301 to 700 employees & 32 \\
\hline Over 701 employees & 30 \\
\hline
\end{tabular}


Table 8. Type of Companies

\begin{tabular}{l|c}
\hline \multicolumn{1}{c|}{ Type of Company } & Number of Companies \\
\hline Automotive (supplier) & 47 \\
\hline Automotive (manufacturer) & 10 \\
\hline Aerospace, Defense, Electronics and Communications products & 9 \\
\hline $\begin{array}{l}\text { Others: Biomedical, Chemical and Process Industry, Food, } \\
\text { Plastic Card Manufacturing, Plastic packaging Supplier to } \\
\text { Consumer Goods }\end{array}$ & 18 \\
\hline Total & \\
\hline
\end{tabular}

\subsection{Research Question 1}

What is the relationship between organizational climate and the three implementation outcomes of lean manufacturing in manufacturing organizations? In this study, organizational climate consists of three dimensions of open-mindedness, creativity, and continuous improvements. As revealed in Table 9, open-mindedness is positively correlated with quality and waste, but it shows lower, significant positive correlation with delivery.

Creativity shows a significant positive correlation with quality, waste, and delivery. Continuous improvements reveal a stronger significant positive correlation with quality and a low, but still significant positive correlation with waste and delivery outcomes.

In general, open-mindedness, creativity, and continuous improvement revealed the strongest correlation with quality outcomes. Also, organizational climate (combination of three dimensions of open-mindedness, creativity, and continuous improvement) indicated a strong significant positive correlation with quality $(\mathrm{r}=.624, \mathrm{p}<.01)$, and lower but still a significant positive correlation with waste $(\mathrm{r}=.467, \mathrm{p}<.01)$ and delivery $(\mathrm{r}=.360, \mathrm{p}<.01)$.

Based upon these results per participants' perception, organizational climate is a variable that should be given serious consideration when implementing lean manufacturing.

Table 9. Correlations Between Organizational Factors and Implementation Outcomes of Lean

\begin{tabular}{|c|c|c|c|c|c|c|c|c|c|c|}
\hline Variables & 1 & 2 & 3 & 4 & 5 & 6 & 7 & 8 & 9 & 10 \\
\hline $\begin{array}{l}\text { 1. Open- } \\
\text { mindedness }\end{array}$ & & & & & & & & & & \\
\hline 2. Creativity & $0.690^{* *}$ & & & & & & & & & \\
\hline 3. Continuous & $0.530^{* *}$ & $0.606^{* *}$ & & & & & & & & \\
\hline 4. Centralization & $0.632^{* *}$ & $0.494^{* *}$ & $0.661^{* *}$ & & & & & & & \\
\hline 5. Integration & $0.650^{* *}$ & $0.671^{* *}$ & $0.629^{* *}$ & $0.646^{* *}$ & & & & & & \\
\hline 6. Formalization & 0.027 & $0.124^{* *}$ & $0.330^{* *}$ & 00.134 & $0.273^{*}$ & & & & & \\
\hline $\begin{array}{l}\text { 7. Organizational } \\
\text { Structure }\end{array}$ & $0.615^{* *}$ & $0.601^{* *}$ & $0.724^{* *}$ & $0.809^{* *}$ & $0.888^{* *}$ & $0.553^{* *}$ & & & & \\
\hline 8. MPS & $0.322^{* *}$ & $0.458^{* *}$ & $0.462^{* *}$ & $0.483^{* *}$ & $0.535^{* *}$ & $0.306^{* *}$ & $0.591^{* *}$ & & & \\
\hline 9. Quality & $0.496^{* *}$ & $0.579^{* *}$ & $0.540^{* *}$ & $0.482^{* *}$ & $0.659^{* *}$ & $0.279^{*}$ & $0.644^{* *}$ & $0.504^{* *}$ & & \\
\hline 10. Waste & $0.442^{* *}$ & $0.432^{* *}$ & $0.344^{* *}$ & $0.371^{* *}$ & $0.370^{* *}$ & 00.096 & $0.384^{* *}$ & $0.333^{* *}$ & $0.610^{* *}$ & \\
\hline 11. Delivery & $0.246^{*}$ & $0.337^{* *}$ & $0.343^{* *}$ & $0.313^{* *}$ & $0.243^{*}$ & 00.188 & $0.326^{* *}$ & $0.332^{* *}$ & $0.509^{* *}$ & $0.829^{* *}$ \\
\hline
\end{tabular}

Note: Correlation is significant at the 0.01 level, ${ }^{* *} \mathrm{p}<0.001$ (two-tailed); Correlation is significant at the 0.05 level, ${ }^{*} \mathrm{p}<0.05$ (two-tailed). 


\subsection{Research Question 2}

What is the relationship between organizational structure and the three implementation outcomes of lean manufacturing in manufacturing organizations? In this study, organizational structure consists of centralization, integration, and formalization.

Centralization has a significant positive correlation with quality, waste, and delivery. Integration has a strong significant positive correlation with quality $(\mathrm{r}=.659, \mathrm{p}<.01)$, but has less significant positive correlation with waste and delivery. Formalization has only a significant positive correlation with quality, and no significant correlation with delivery or waste. In other words, this finding indicates that formalized jobs, work processes, and documentation affect quality but not waste and delivery outcomes. However, formalization is an important factor for implementation and sustainability of lean manufacturing, since the commonly understood method for carrying out every necessary step in every process, and reviewing and updating all documents periodically is highly encouraged by lean philosophy.

Moreover, organizational structure (combination of three dimensions of centralization, integration, and formalization) revealed a strong significant positive correlation with quality $(\mathrm{r}=.644, \mathrm{p}<.01)$, and lower but still significant positive correlation with waste and delivery outcomes.

In general, even though the results of this study show that quality had the strongest correlation with organizational structure in comparison with waste and delivery outcomes, they also indicate that organizational structure requires significant attention when companies attempt to implement lean manufacturing.

\subsection{Research Question 3}

What is the relationship between job design and the three implementation outcomes of lean manufacturing in manufacturing organizations? As revealed in Table 9, Motivating Potential Score (MPS) has a significant positive correlation with quality, and less but still significant positive correlation with waste and delivery outcomes.

The results of this study indicate that job design is a factor that affects the perceptions of lean manufacturing outcomes and therefore should be given considerable attention when implementing lean manufacturing.

All three independent variables of organizational climate, organizational structure, and job design, even though indicating significant positive correlation with implementation outcomes of lean manufacturing (except for lack of correlation between formalization with waste and delivery), indicated their strongest correlation with quality (Figure 2, where an arrow indicates that correlation is significant at the 0.01 level (two-tailed) or at the 0.05 level (two-tailed)).

Figure 2. Correlation Between Organizational Factors and Outcomes of Lean Manufacturing

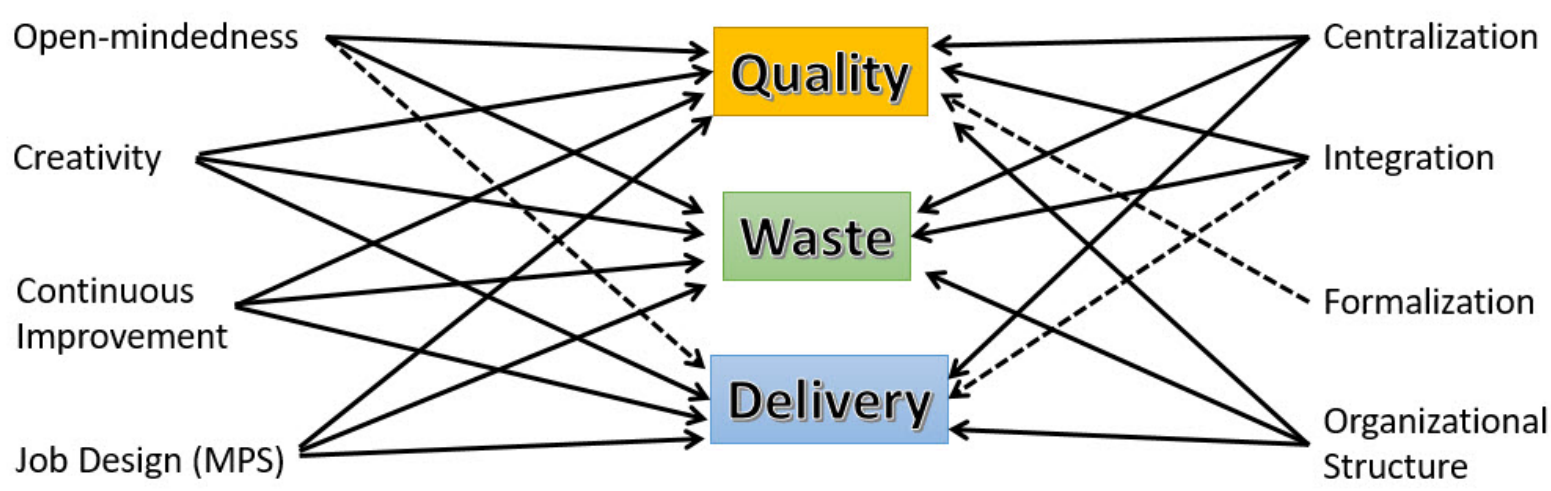

Correlation is significant at the 0.01 level (two-tailed) Correlation is significant at the 0.05 level (two- tailed)

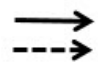




\subsection{Multiple Regression Analysis}

The multiple regression procedure of each of the organizational factors on the quality outcome revealed that $47 \%$ of the variance in quality is explained by the combined independent factors; on the waste outcome it revealed that $23 \%$ of the variance in waste is explained by the combined independent factors, and on the delivery outcome it revealed that $16 \%$ of the variance in delivery is explained by the combined independent factors and that these multiple regressions are statistically significant. The results indicate that the correlation between organizational factors and quality, waste, and delivery are higher than the single correlations of each factor (Table 10). Overall, organizational climate has the highest impact on the three implementation outcomes of lean manufacturing and therefore organizations should pay attention to this variable.

Table 10. Regression Analysis of Combined Independent Factors on Implementation Outcomes

\begin{tabular}{|c|c|c|c|c|c|c|c|c|c|}
\hline & \multicolumn{3}{|c|}{ Quality } & \multicolumn{3}{|c|}{ Waste } & \multicolumn{3}{|c|}{ Delivery } \\
\hline & r2 & $\beta$ & Sig & $\mathrm{r} 2$ & $\beta$ & Sig & $\mathrm{r} 2$ & $\beta$ & Sig \\
\hline & 0.477 & & 0 & 0.233 & & 0 & 0.162 & & 0.003 \\
\hline Organizational Climate & & 0.14 & & & 0.361 & & & 0.09 & \\
\hline Organizational Structure & & 0.2 & & & -0.13 & & & 0.008 & \\
\hline Job Design & & 0.001 & & & 0.002 & & & 0.09 & \\
\hline Constant B & & 3.145 & & & 9.036 & & & 10.439 & \\
\hline
\end{tabular}

Note: Regression Analysis of Organizational Structure, Organizational Climate, and Job Design on Quality, Waste and Delivery Outcome Variables

Within each of the multiple regression procedures, there is a high degree of correlation with the independent factors. This implies that multicollinearity exists among these variables which in turn is suppressing the actual amount of variance explained.

\section{SUMMARY AND CONCLUSIONS}

The purpose of this cross-sectional correlation study was to investigate the possible relationship between organizational factors, as independent variables, and implementation outcomes of lean manufacturing. This correlation study, which was based on the perception of participating managers, indicated that, except for the lack of a significant correlation between formalization with waste and delivery, there were positive significant correlations between all other organization factors and implementation outcomes of lean manufacturing. With regard to formalization, even though a high degree of formalization causes centralization of authority, for implementation and sustainability of lean manufacturing, a right balance must be created between the standardizing operations and the employees' freedoms to perform their job with flexibility and creativity. Therefore, lack of attention to formalization affects companies' ability for continuous improvement due to the lack of specific and commonly understood methods to carry out every important step in every process. These study findings show that all organizational activities, directly or indirectly, affect quality, waste, and delivery.

Since the results of this study indicate lack of significant correlation between formalization and waste and delivery, which does not support lean manufacturing philosophy - as process standardization and discipline are required for continuous improvement and from there, successful implementation and sustainability of lean manufacturing future research can validate these findings.

A natural direction for future research is to evaluate the effect of moderating factors that were considered in this empirical study - namely, the length of time that lean manufacturing has been implemented, the company's size, and the type of manufacturing - on the relationship between organizational factors and quality, waste, and delivery. The effects of the length of time that lean manufacturing has been implemented in a manufacturing organization, or the company's size, or type of manufacturing on the relationship between organizational factors and the three implementation outcomes of lean manufacturing are promising research questions to address. So are other relevant moderating factors. As the relationship between organizational factors and implementation outcomes of lean manufacturing may be attributed to other organizational and moderating factors, future research can further expand based on the research model, findings, and the results of this research study. 


\section{LIMITATIONS}

This study sought participation of individuals who are in different levels of managerial position and engineers with good experience with lean manufacturing who were willing to spend time to answer 60 questions. Due to busy schedules and time unavailability of this type of individual, the participants sample population was limited to 84 individuals. This study relied on the perception of participants and, therefore, the results are only generalized to this type of occupation.

\section{ACKNOWLEDGEMENTS}

The authors would like to acknowledge the recommendations of the anonymous reviewers and the editorial guidance of the Editor-In-Chief that have markedly improved the quality of this paper.

\section{AUTHOR BIOGRAPHY}

Homayoun Bayat is Senior Supplier Development Engineer at General Motors Powertrain Global Headquarters. Dr. Bayat earned his PhD in Technology from Eastern Michigan University and serves as an Adjunct Professor of Operations Management at Oakland University. Dr. Bayat's certifications include: Certified Process Failure Mode and Effect Master Black Belt (General Motors); Certified Six Sigma Black Belt (Michigan Manufacturing Technology Center - MMTC); and Certified Supplier Quality Engineer (General Motors).

Mohammad Dadashzadeh serves as a professor in the department of Decision and Information Sciences (DIS) at Oakland University. He has authored more than 50 articles on decision sciences and has served as the editor-in-chief of Journal of Database Management.

\section{REFERENCES}

Alony, I., \& Jones, M. (2008). Lean supply chains, JIT and cellular manufacturing - the human side. Issues in Informing Science and Information Technology, 5, 165-175.

American Society for Quality. (2000). Certified Quality Engineer: Glossary Index. Milwaukee, Wisconsin: American Society for Quality.

Bayat, H., \& Dadashzadeh, M. (2016). Organizational Success Factors of Lean Manufacturing: Research Review. International Journal of Business, Marketing, and Decision Sciences, 9(1), 1-18.

Besterfield, D. (1986). Quality control. New Jersey: Prentice-Hall.

Broh, R.A. (1982). Managing quality for higher profits. New York: Mc Graw- Hill.

Caruana, A., Morris, M.H., \& Vella, A.J. (1998). The effect of centralization and formalization on entrepreneurship in export firms. Journal of Small Business Management, 36(1), 16-29.

Crosby, P.B. (1979). Quality is free. New York: Mc Graw- Hill.

Cummings, S. (1995). Centralization and decentralization: The never-ending story of separation and betrayal. Scandinavian Journal of Management, 11(2), 103-117.

DeGroot, T., \& Brownlee, A. L. (2006). Effect of department structure on the organizational citizenship behavior-department effectiveness relationship. Journal of Business Research, 59, 1116-1123.

de Treville, S., \& Antonakis, J. (2006). Could lean production job design be intrinsically motivating? Contextual, configurational, and levels-of-analysis issues. Journal of Operations Management, 24 (2), 99-123.

Doolen, T. L., \& Hacker, M. E. (2005). A review of lean assessment in organizations: An exploratory study of lean practices by electronics manufacturers. Journal of Manufacturing Systems, 24(1), 55-67.

Drew, J., McCallum, B., \& Roggenhofer, S. (2004). Journey to lean. Making operational change sticks. New York: Palgrave Macmillan.

Hackman, J. R., \& Oldham, G. R. (1976). Motivation through the design of work: Test of a theory. Organizational Behavior and Human Performance, 16, 250-279.

Hage, J, \& Aiken, M. (1967). Relationships of centralization to other structural properties, Administrative Science Quarterly, 12 (1), 72 -92 .

Hicks, B. J. (2007). Lean information management: Understanding and eliminating waste. International Journal of Information Management, 27, 233-249.

Hoyte, D. S., \& Greenwood, R. A. (2007). Journey to the north face: A guide to business transformation. Academy of Strategic Management Journal, 6, 91-104.

Huge, E. C., \& Anderson, A. D. (1988). The spirit of manufacturing excellence. The Dow Jones- Irwin/APICS Series in Production Management. 
Jackson, P.R., \& Martin, R. (1996). Impact of Just-In-Time on job content, employee attitudes and well -being: A longitudinal study. Ergonomics, 39(1), 1-16.

Jones, G. R. (2010). Organizational theory, Design, and change. New Jersey: Pearson Prentice Hall.

Lawrence, P. R., \& Lorsch, J. W. (1967). Differentiation and integration in complex organizations. Administrative Science Quarterly, $12(1), 1-47$.

Leedy, P. D., \& Ormrod, J. E. (2005). Practical research, planning and design. New Jersey: Pearson Prentice Hall.

Liker, J., K. (1998). Becoming lean. Portland, OR: Productivity Press.

Liker J. K. (2004). The Toyota way: 14 management principle from the world's greatest manufacturer. New York: McGraw-Hill.

Laureani, A., \& Antony, J. (2012). Critical success factors for the effective implementation of Lean Sigma. International Journal of Lean Six Sigma, 3(4), 274.283

Mehta, V., \& Shah, H. (2005). Characteristics of a work organization from a lean perspective. Engineering Management Journal, 17(2), 14-20.

Morgan, G. A., Leech, N. L., Gloeckner, G. W., \& Barrett, K. C. (2007). SPSS for introductory statistics: Use and interpretation. Mahwah, NJ: Lawrence Erlbaum.

Naveh, E., \& Erez, M. (2004). Innovation and attention to detail in the quality improvement paradigm. Management Science, 50(11), $1576-1586$.

Ohno, T. (1988). Toyota production system - Beyond large scale production. Cambridge, MA: Productivity Press.

O'Leary-Kelly, S. W., \& Flores, B. E. (2002). The integration of manufacturing and marketing/sales decisions: Impact on organizational performance. Journal of Operations Management, 20, 221-240.

Payne, R., \& Mansfield, R. (1978). Correlates of individuals' perceptions of organization climate. Journal of Occupational Psychology, 51, 209-218.

Roffe, I. (1999). Innovation and creativity in organizations: A review of the implications for training and development. Journal of European Industrial Training, 23(4/5), 224-241.

Shah, R., \& Ward, P.T. (2003). Lean manufacturing: Context, practice bundles, and performance. Journal of Operations Management, $21,129-149$.

Stern, D., Song, Y., \& O’Brien, B. (2004). Company training in the United States 1970-2000: What have been the trends over time? International Journal of Training and Development, 8(3), 191-209.

Wickramasinghe, D., \& Wickramasinghe, V. (2011). Differences in organizational factors by lean duration. Operations Management Research, 4, 111-126.

Womack, J. P., Jones, D. T. (2003). Lean thinking: Banish waste and create wealth in your corporation. New York: Free Press.

Womack, J. P., Jones, D. T., \& Roos, D. (2007). The machine that changed the world. New York: Free Press.

Worley, J. M., \& Doolen, T. L. (2014). Organizational structure, employee problem solving, and lean implementation. International Journal of Lean Six Sigma, 6(1), 39-58. 
NOTES 